\title{
Lipids, pots and food processing at Hočevarica, Ljubljansko barje, Slovenia
}

\author{
Nives Ogrinc 1, Mihael Budja 2, Doris Potočnik 1, Andreja Žibrat Gašparič² \\ and Dimitrij Mlekuž 2 \\ 1Department of Environmental Sciences, Jožef Stefan Institute, Ljubljana, SI \\ nives.ogrinc@ijs.si; doris.potocnik@ijs.si \\ 2Department of Archaeology, Faculty of Arts, University of Ljubljana, SI
}

\begin{abstract}
The paper presents the results of lipid analyses of pottery samples from Hočevarica (Ljubljansko barje, Slovenia). Total lipid extracts were subjected to high temperature gas chromatography (HT-GC), gas chromatography- mass spectrometry (GC-MS) and gas chromatography-combustion-isotope ratio mass spectrometry (GC-C-IRMS). The results show that some vessels were used for preparing ruminant meat and vegetable, but also the remains of aquatic food were identified. The processing of non-ruminant meat was detected in a few samples. A high number of pottery samples yielded the presence of beeswax lipids. The charred residual on pottery was AMS ${ }^{14} \mathrm{C}$ dated.

IZVLEČEK - V članku predstavljamo rezultate analiz lipidov ohranjenih v keramičnem zbiru s Hočevarice. Lipide, ekstrahirane iz ostankov keramičnih posod, smo analizirali s pomočjo plinske kromatografije pri visokih temperaturah (HT-GC), plinske kromatografije sklopljene z masno spektrometrijo (GC-MS) in plinske kromatografije sklopljene z masnim pektrometrom za analizo stabilnih izotopov lahkih elementov preko sežigne enote (GC-C-IRMS). Rezultati kažejo, da so v posodah pripravljali hrano iz mesa prežvekovalcev in zelenjave; redko iz mesa neprežvekovalcev. V drugih so pripravljali hrano iz sladkovodnih rib. V številnih posodah je bil odkrit čebelji vosek. Karbonizirani ostanki na posodah so bili AMS ${ }^{14} \mathrm{C}$ datirani.
\end{abstract}

KEY WORDS - lipid analysis; ${ }^{14} \mathrm{C}$ dates; pottery; Eneolithic; Ljubljansko barje

\section{Introduction}

Hočevarica is located at the outfall of Hočevarica drainage channel into the Ljubljanica River between Blatna Brezovica and Verd on the western part of the Ljubljansko barje area (Fig. 1). A small trench $\left(8 \mathrm{~m}^{2}\right)$ was excavated in 1998 (Velušček 2004a). The site was recognised as a pile-dwelling settlement embedded in the time span 3650-3520 calBC (for wood samples) (Čufar, Kromer 2004.283) and 3640-3530 calBC (for short-lived seed and carbonised grain samples) (Jeraj 2004.59).

The site stratigraphy consists of ten layers (Fig. 2). While some are of geological provenance, layers 4-8 relate to settling and can be associated with two settlement phases (Velušček 2004b.37-40; 2004c.213-
217). Patches of burnt clay and daub (e.g., house remains) are deposited in well-defined stratigraphic superposition; they correlate with the distribution of vertical wooden piles, and depositions of pottery, stone and wooden tools within the stratified settlements' layers (ibid. 40-47).

\section{Palaeobotany and archaeozoology}

More than 30000 remains of seeds and fruits of cultivated and gathered wild plants have been found in both settlement contexts. While cereal grains were carbonised, most of the remaining plant remains were unburned. The grains of cultivated Hordeum vulgare (six-rowed barley), Triticum monococcum 
(einkorn wheat) and Triticum dicoccum (T. turgidum ssp. Dicoccum, emmer wheat) were identified; the most abundant cereal at Hočevarica is barley.

However, the remains of wild nuts, fruits and seeds predominated in the archaeobotanical assemblage, comprising Quercus sp. Cupulae (acorn), Corylus avellana (hazelnut), Malus sylvestris (crab apple), Prunus avium (wild cherry), Cornus mas (Cornelian cherry), Cornus sanguinea (common dogwood), Prunus spinosa (blackthorn), Rubus fruticosus (blackberry), Fragaria vesca (wild strawberry), Physalis alkekengi (winter cherry), and Trapa natans (water chestnut). Along with $\mathrm{Pa}$ -

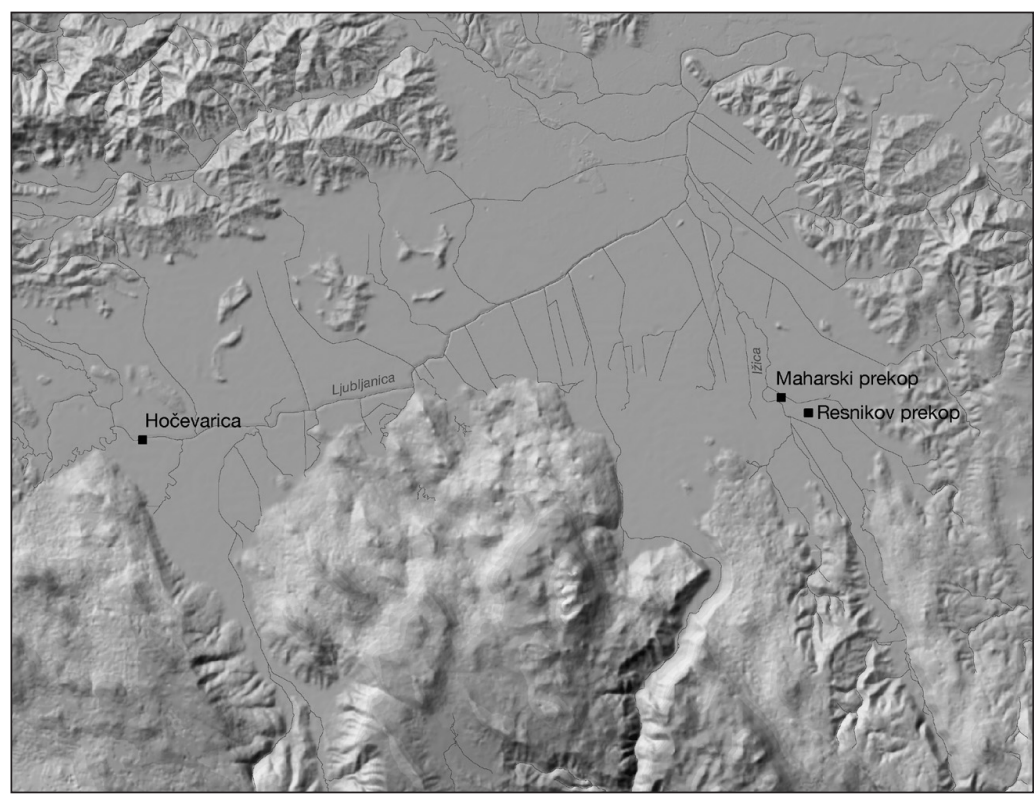

Fig. 1. Map of Ljubljansko barje region with the position of the site at Hočevarica. paver somniferum (opium poppy) seeds, the only remains of an oily plant, Chenopodium album (goosefoot), which has seeds rich in oil and starch, were also gathered. Pulses such as Lathyrus sativus (grass pea) and Vicia sp. (Vitis vinifera ssp. Sylvestris, wild grapevine) were found in small numbers in the $1^{\text {st }}$ settlement phase (Jeraj 2004.58-59; 2009. 79-82).

It was suggested that while cereals were cultivated in fields situated on moist to damp soils close to the settlement, wild nuts, fruits and seeds were collected along the forest edges and in clearings around the settlement. The water plants were collected in small and shallow meso- to eutrophic lakes which warm up in summer. All the wild plants have been processed in settlement contexts (Tolar et al. 2011.216).

\begin{tabular}{|c|c|c|c|c|c|}
\hline Lab code & Material & Phase & $\begin{array}{c}14 \mathrm{C} \text { Conven- } \\
\text { tional } \\
\text { age BP }\end{array}$ & $\begin{array}{l}\text { Calibrated } \\
\text { date } \\
\text { calBC }(2 \sigma)\end{array}$ & Reference \\
\hline Hd-18976 & wood & & $4822 \pm 39$ & $3695-3521$ & $\begin{array}{l}\text { Čufer, Kromer 2004.Tab. } \\
\text { G.3.2 }\end{array}$ \\
\hline Hd-22139 & wood & & $4867 \pm 26$ & $3702-3636$ & Cufar et al. 2010.Tab. $4^{*}$ \\
\hline $\mathrm{Hd}-20765$ & wood & & $4748 \pm 26$ & $3636-3382$ & Cufar et al. 2010.Tab. $4^{*}$ \\
\hline $\mathrm{Hd}-22305$ & wood & & $4825 \pm 25$ & $3656-3530$ & Cufar et al. 2010.Tab. 4* \\
\hline ? & $\begin{array}{l}\text { organic } \\
\text { sediment }\end{array}$ & & $4780 \pm 40$ & $3648-3383$ & Jeraj 2004.62** \\
\hline ?? & seed & 2 & $4780 \pm 40$ & $3648-3383$ & Jeraj 2004.59 \\
\hline ??? & grain & 1 & $4810 \pm 40$ & $3691-3518$ & Jeraj 2004.59 \\
\hline Beta-391181 & food residue & 2 & $4910 \pm 30$ & $3763-3642$ & \\
\hline Beta-391176 & food residue & 1 & $4860 \pm 30$ & $3704-3539$ & \\
\hline Beta-391182 & food residue & 2 & $4770 \pm 30$ & $3641-3519$ & \\
\hline Beta-391178 & bos taurus & 1 & $4760 \pm 30$ & $3641-3384$ & \\
\hline Beta-391183 & ovis/capra & 2 & $4740 \pm 30$ & $3639-3379$ & \\
\hline Beta-391185 & Cornus stone & 2 & $4720 \pm 30$ & $3635-3376$ & \\
\hline Beta-391180 & Cornus stone & 1 & $4680 \pm 30$ & $3623-3370$ & \\
\hline Beta-391177 & food residue & 1 & $4780 \pm 30$ & $3635-3531$ & \\
\hline
\end{tabular}

Tab. 1. Radiocarbon dates from Hočevarica. Dates marked with an asterisk (*) are inconsistently published (Hd-22139 as $4972 \pm 25$ and Hd-20765 as $4746 \pm 26$ in Čufar, Kromer 2004). Date for organic sediment (marked by **) by Jeraj (2004) is the same age as date for seed in phase 2. Since Jeraj does not cite lab codes for dates, it is possible that both are the same sample.

The animal bone assemblage consists of 4352 animal remains. About a third of them are fishes and birds, the remainder $(63.4 \%)$ are mammals. The mammal bones (2757 total) are from at least 14 species (Toškan, Dirjec 2004.76-132). Roe deer (Capreolus capreolus) remains predominate, comprising a good third of the mammalian assemblage; the second most frequent was $\mathrm{pig} /$ wild boar (Sus sp.), accounting for one third. Other species were less frequent. Only red deer (Cervus elaphus), beaver (Castor fiber), $\operatorname{dog}$ (Canis familiaris), and the remains of sheep and goat (Ovis s. Capra) exceeded 5\% of all finds. While Sus scrofa/domesticus bones 
predominate $(38.2 \%)$ in the 1 st settlement phase, Ovis s. Capra remains are the most frequent (19.7\%) in the $2^{\text {nd }}$ phase (ibid. 80 ).

The evidence of animal slaughter and further meat processing at the site are weak. The proportion of bones with cut and chop marks and/or traces of boiling or roasting was below $10 \%$. However, the analysis of tooth wear showed that most of the pigs were slaughtered in the autumn at an assessed age of 17 to 22 months, and during winter or in early spring, at a probable age of 22 to 27 months (Toškan, Dirjec 2004.121). The fish remains consist of five species: common carp, rudd, pike, perch and roach. The carp and rudd remains predominate ( $\mathrm{GO}$ vedič 2004.133-151).

\section{Chronology}

The Hočevarica radiocarbon sequence is comprised of 13 AMS radiocarbon dates. In addition to the series of four dates on wooden piles used to anchor the dendrochronological sequence and two dates obtained on shortlived botanical samples, an additional two AMS radiocarbon dates from animal bones, two AMS dates on short-lived botanical samples and four dates of carbonised food residues on pottery were obtained recently (Tab. 1).

Complementary samples allow a better understanding of the chronology of activities at the site. The radiocarbon dates of bones and carbonised food/organic residues on pottery date events relating to the preparation and disposal of food, and thus complement the dates of the wooden structures relating to building and construction events. The floating oak chronology of 139 years from Hočevarica (HOC-QUSP1) is dated between 3685 and $3547( \pm 10)$ BC, which suggests an end to building activities after around 3550 BC ( $\breve{C} u f a r$ et al. 2010).

On the other hand, the majority of AMS dates on short-lived samples concentrate between 3630-3350 calBC (Fig. 3). The wide spread of values can be attributed to a wiggles in the calibration curve between 3620-3520 and 3480-3380 calBC. However, it seems that activities at the site reflected in the short-lived sam- ples began well before the end of the building activities, before $3600 \mathrm{calBC}$, and continued for a few decades after building activities had ended. This long span of activities corresponds well with the two settlement phases.

Two dates on charred food residues on pottery are older than the oldest dates on the wooden piles. Lipid analysis on one sample (Beta-391176) from the first phase yielded a lipid concentration high enough (01HO; Tab. 2) to suggest that the pot was used to cook a ruminant/plant mixture. The concentration of lipids in the other sample (Beta-391181, 18HO; Tab. 2) was too low to allow a determination of foodstuffs. However, as this sample is associated with the second phase, it appears too old. At the moment, we have no dates on fish bones or food residues associated with aquatic foodstuffs that would demonstrate the presence of a reservoir effect. Therefore, both early dates could suggest earlier activities at the site or a reservoir effect.

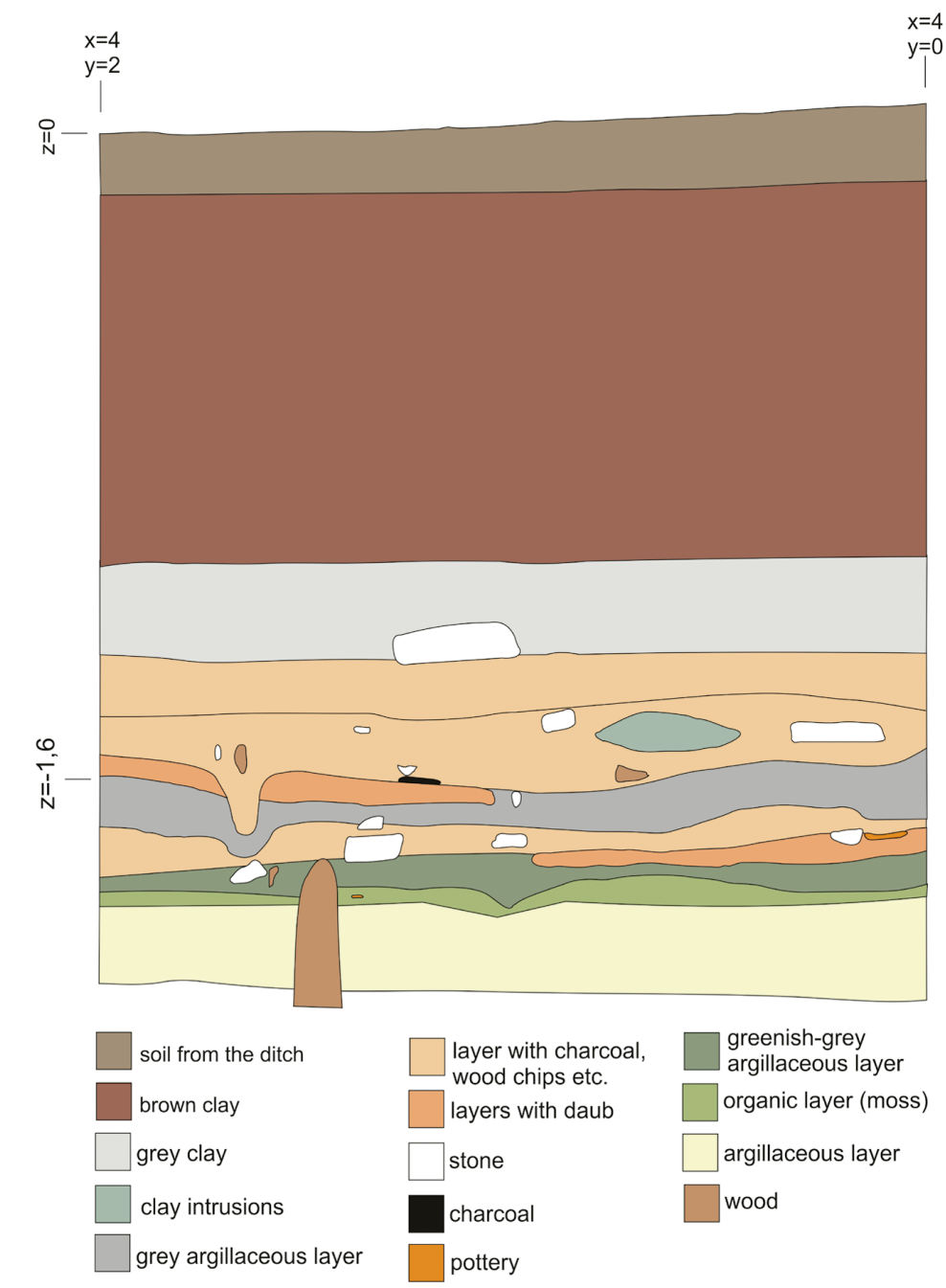

Fig. 2. Northern cross-section of the trench at Hočevarica (after Velušček 2004.Fig. 3.1.5). 


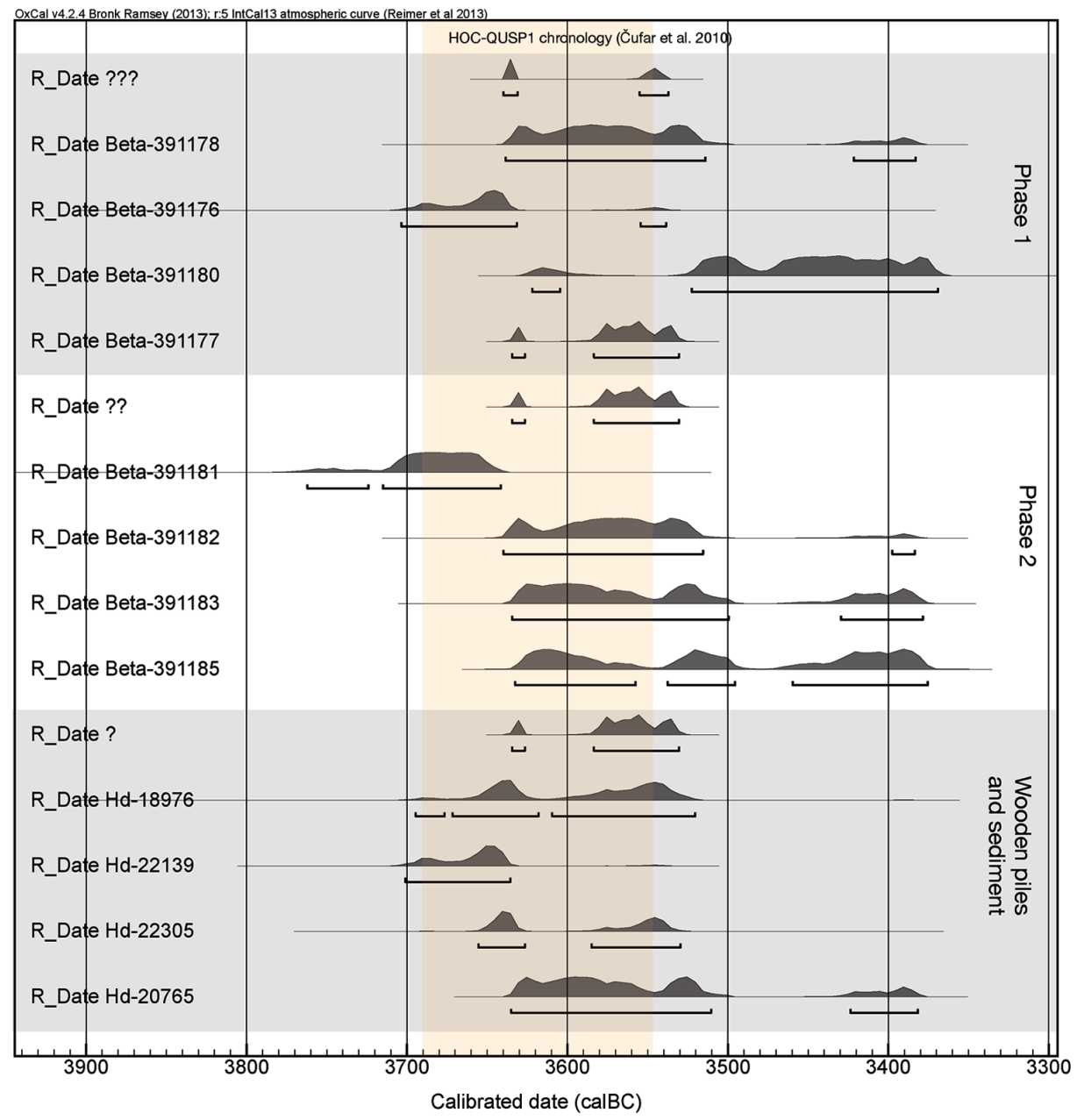

Fig. 3. Calibrated radiocarbon dates from Hočevarica in relation to the HOC-QUSP1 chronology.

These new dates suggest a long and complex chronological sequence for the Hočevarica site. It appears that the site was settled for almost 200 years, had two distinct phases of occupation, and shows possible evidence of activities before the wooden structures were built.

\section{The pottery}

For the present study, we analysed 35 pottery samples from Hočevarica by hand lens to identify inclusions, their size and frequency, and the presence of voids. The samples were chosen on the basis of typology (see Velušček 2004d.169-212) and on the basis of the presence of charred food remains on the interior surface of the vessels. Most of the samples came from fragments of vessel rims and walls; only 9 samples were attributed to types according to their morphology: 3 pots, 4 dishes, and 2 bowls (Fig. 4; Tab. 2).

The vessel types are similar to the pottery assemblage from the contemporary site at Maharski pre- kop in the south-eastern part of Ljubljansko barje (Bregant 1974a; 1974b; 1975; Velušček 2004d. 184-212). The majority of the vessels can be attributed to various types of pots (Velušček 2004d.186194) and dishes (ibid. 196-203), but other forms are also present (cups, miniature vessels, hanging vessels and other special forms; ibid. 195, 203).

Similarly, the technological characteristics of the Hočevarica pottery assemblage are comparable to vessels from Maharski prekop (Žibrat Gašparič 2013. 153-155). The vessels area primarily dark grey, brown and black, and most were fired in a reducing atmosphere. Most of the pottery is poorly made and prone to mechanical decomposition; only the decorated vessels are of better quality and have polished surfaces or slips applied to the surface (Velušček 2004d.184-185).

We could divide the pottery samples into two technological groups according to their inclusions (descriptions after Horvat 1999): most of the samples have calcite/limestone inclusions $(82.8 \%)$, while the 

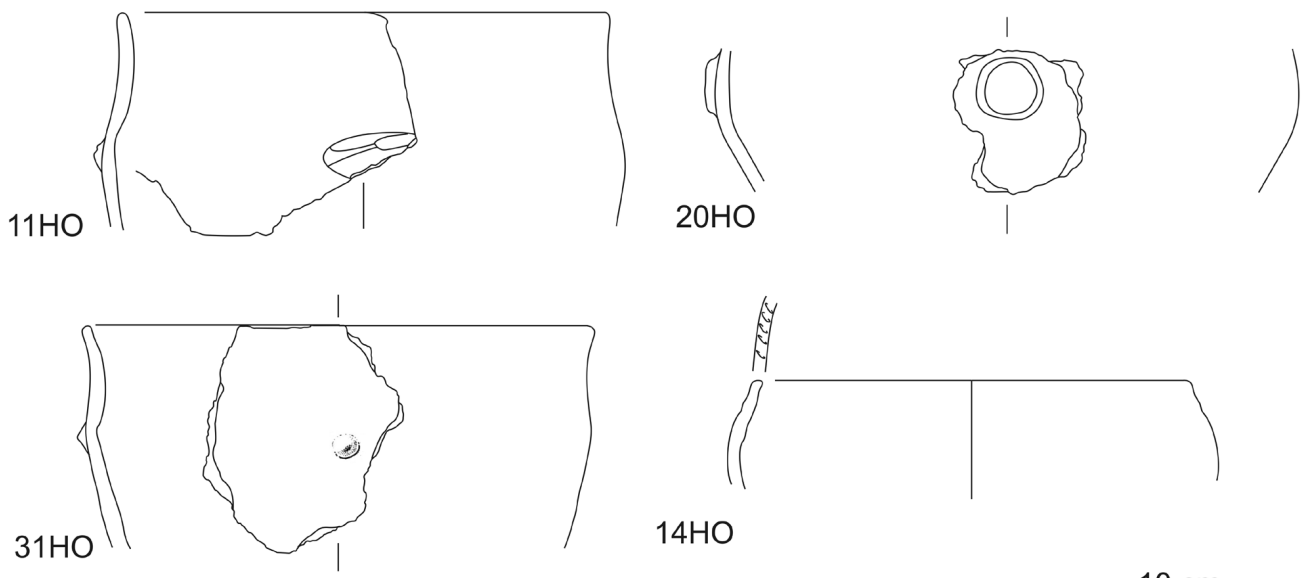

$14 \mathrm{HO}$
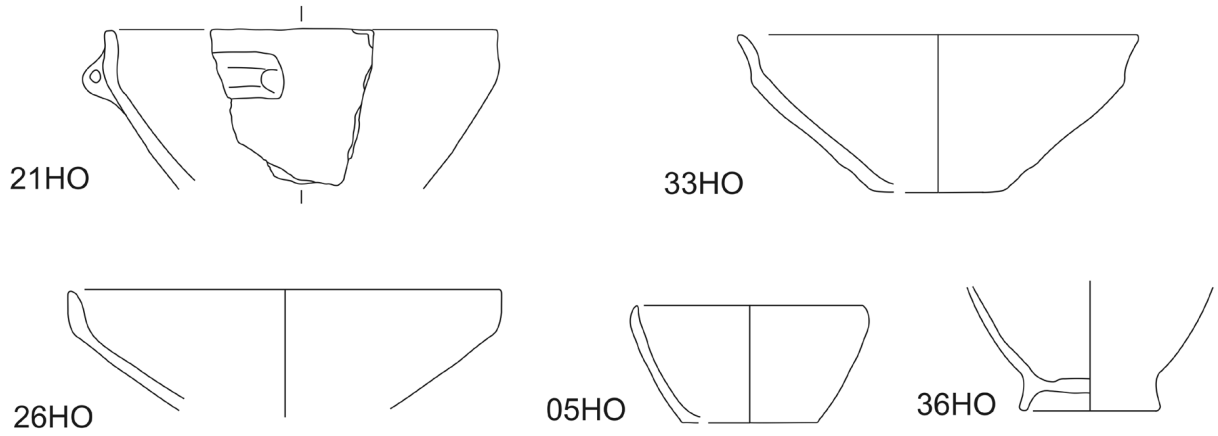

Fig. 4. Pottery samples bearing traces of ruminant fat (14HO, 33HO), mixed animal fats (05HO), mixed animal and plant fats (31HO), mixed animal fats and beeswax (21HO, 26HO, 36HO), freshwater animal oils (11HO) and a mixture of dairy fat and beeswax (20HO) (drawings after Velušček 2004a.169-183).

remainder are made of non-calcareous clay and have only quartz inclusions (17.2\%). In the group with quartz, most of the inclusions comprise very fine (less than $0.25 \mathrm{~mm})$ or medium-size sand $(0.25$ to $0.50 \mathrm{~mm})$. Most of the samples with calcite/limestone have medium-size sand inclusions $(0.25$ to $0.50 \mathrm{~mm})$, but coarse sand is present $(0.50$ to $2.00 \mathrm{~mm})$ in a third of the samples.

The pottery samples from Hočevarica have voids, usually on both surfaces, in the size of medium to coarse sand fraction, and many have an angular shape similar to calcite crystals. This could be the result of calcite dissolved from the vessels. Such chemical changes in pottery are common post-depositional processes (Rice 1987.421). A similar situation could be observed at the contemporary site at Krašnja near Lukovica (Žibrat Gašparič et al. 2014).

All the pottery samples were handmade and their surfaces burnished; smoothing and polishing were also present. One of the vessels (10HO) was decorated with a grey-black slip on both the interior and exterior surfaces. They were fired in an incomplete oxidising (51.4\%) and a reducing atmosphere (34.3\%), while the other samples were fired in a reducing at- mosphere with an oxidising atmosphere at the end of firing.

The pottery from the calcite/limestone group at Hočevarica has characteristics very similar to fabric MP1 from Maharski prekop, which is a non-calcareous clay with frequent calcite grains added as temper and is the most common fabric found at that site (Žibrat Gašparič 2013.154). On the other hand, the group with quartz inclusions from Hočevarica differs from the fabrics described at Maharski prekop and could display a new technology in the later phase of the settlement, since the samples of the quartz group all come from the $2^{\text {nd }}$ settlement phase at Hočevarica. This hypothesis would have to be tested with additional pottery samples, as well as with a petrographical analysis of thin sections.

\section{Materials and methods}

A total of 36 selected pottery samples were first cleaned to remove exogenous lipids, and then ground to a fine powder. For lipid extraction, about $2 \mathrm{~g}$ of sample were transferred to a $50 \mathrm{ml}$ vial and $20 \mu \mathrm{l}$ of internal standard ( $n$-tetratriacontane, $1 \mathrm{mg} / \mathrm{mL}$ in $n$ hexane) were added. Lipids were ultrasonically ex- 
tracted with a mixture of methanol and chloroform $(1: 2 \mathrm{v} / \mathrm{v}, 24 \mathrm{~mL}, 2 \times 30 \mathrm{~min})$. The solvent extract was removed into a glass flask and reduced to a small volume by rotary evaporation. The residue of solvent extract was transferred to a $2 \mathrm{ml}$ glass vial and evaporated to dryness under a gentle stream of nitrogen to obtain the total lipid extract (TLE). The aliquot $(500 \mu \mathrm{l})$ of the TLE was treated with BSTFA (N, O-bis(trimethylsilyl)-trifluoroacetamide, $40 \mu \mathrm{\mu} ; 70^{\circ} \mathrm{C}$, $60 \mathrm{~min}$ ), evaporated to dryness and re-dissolved in $n$-hexane. The resulting trimethylsilyl derivatives were analysed using high-temperature gas chromatography (HT-GC) and, where necessary, combined GC-MS analyses were performed to identify the structure of the components (Evershed et al. 1990). All HT-GC analyses were performed on Agilent Technology $6890 \mathrm{~N}$ GC system equipment with DB-5HT capillary column $(15 \mathrm{~m} \times 0.32 \mathrm{~m} \times 0.10 \mu \mathrm{m})$. Temperature program: initial temperature $50^{\circ} \mathrm{C}(1 \mathrm{~min})$, increasing to $350^{\circ} \mathrm{C}(10 \mathrm{~min})$ at a rate of $10^{\circ} \mathrm{C} / \mathrm{min}$. Helium was used as a carrier gas and a flame ionisation detector to monitor the column effluent.

Another aliquot $(500 \mu \mathrm{L})$ of solvent extract was used to prepare free fatty acids methyl esters (FAMEs) by adding $100 \mu \mathrm{L}$ of BF3-methanol (14\% w/v, Sigma Aldrich, $\left.70^{\circ} \mathrm{C}, 60 \mathrm{~min}\right)$. The methyl derivatives were extracted with $n$-hexane and analysed by GC-MS and GC-C-IRMS using standard protocols (Evershed et al. 1994; Mottram et al. 1999; Greg, Slater 2010; Ogrinc et al. 2012). For GC-C-IRMS (Isoprime GV system, Micromass, Manchester, UK) the accuracy of repeated measurements was $\pm 0.3 \%$.

In addition, powder samples ( $\sim 1 \mathrm{mg})$ were analysed by elemental analysis isotope ratio mass spectrometry (IRMS) as previously reported (Ogrinc et al. 2012; Budja et al. 2013). Stable isotope results are expressed as $\delta^{13} \mathrm{C}$ or $\delta^{15} \mathrm{~N}$ values in per mil (\%o) relative to the VPDB and AIR international standard, respectively. The accuracy of measurements was $\pm 0.2 \%$ or $\delta 13 \mathrm{C}$ and $\pm 0.3 \%$ or $\delta 15 \mathrm{~N}$.

\section{Results and discussion}

The average and standard deviations from bulk potsherd samples are $-28.3 \pm 1.6 \%$ and $+4.5 \pm 2.0 \%$ o for $\delta^{13} \mathrm{C}$ and $\delta^{15 \mathrm{~N}}$, respectively (Fig. 5; Tab. 2). These data fall in the range expected for $\mathrm{C}_{3}$ plant and degraded animal tissues whose subsistence was based mainly on $\mathrm{C}_{3}$ plants. The $\delta 15 \mathrm{~N}$ values of terrestrial plant proteins are around $+3 \%$, while proteins derived from terrestrial herbivores from temperate Europe should not exceed $\delta^{15} \mathrm{~N}$ values of $+7.0 \%$ o $(R i$ -

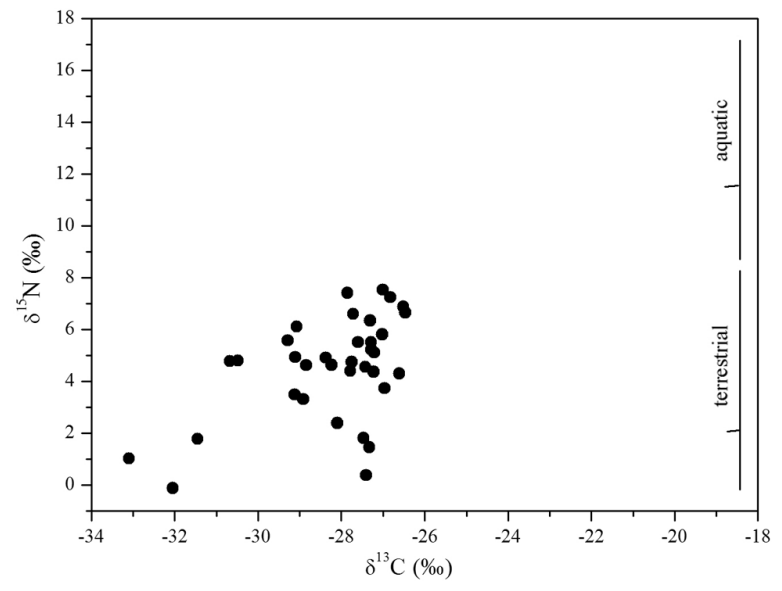

Fig. 5. Bulk stable isotope values of pottery samples from Hočevarica. The vertical bars show 95\% confidence intervals and the median stable nitrogen isotope value from literature data.

chards et al. 2003), although protein derived from domestic animals (such as pigs) may be higher (Privat et al. 2002; Polet, Katzenberg 2003; Richards et al. 2003; Ogrinc, Budja 2005). At Hočevarica, only three samples $(01 \mathrm{HO}, 03 \mathrm{HO}$ and $06 \mathrm{HO})$ have $\delta 15 \mathrm{~N}$ values higher than $+7.0 \%$. Thus the variations in the carbon and nitrogen isotope ratios in our sample show that a wide diversity of animal and plant food was processed in the vessels. No sample has an $\delta 15 \mathrm{~N}$ value greater than $9 \%$ consistent with processing aquatic products with a high trophic level (Fig. 5). However, data on fish species from modern and archaeological samples from lacustrine environments demonstrates a wide range of nitrogen values due to the diverse mixture of aquatic food sources. For example, the $\delta^{15} \mathrm{~N}$ values of freshwater fish in Lake Baikal range from +7.3 to $+13.7 \%$ o (Katzenberg, Weber 1999). And Melanie J. Miller et al. (2010) reported that the modern fish $\delta^{15} \mathrm{~N}$ values of Lake Titicaca range from +4.1 to $+9.5 \%$, while the majority of the $\delta 15 \mathrm{~N}$ values in archaeological fish samples ranged from +5.1 to $+7.7 \%$.

In order to obtain more reliable information on the processing of different commodities in pottery vessels from Hočevarica, more specific chemical and molecular analysis, including lipid analysis, were performed. Lipid preservation in our samples was very good, with more than $75 \%$ of potsherds containing appreciable quantities of lipid (Tab. 2).

\section{Lipid biomarkers}

Even-carbon number $n$-alkanoic acids that range from $\mathrm{C}_{12: 0}$ to $\mathrm{C}_{22: 0}$ were observed in analysed sherds (Fig. 6). In addition, monounsaturated fatty acids 


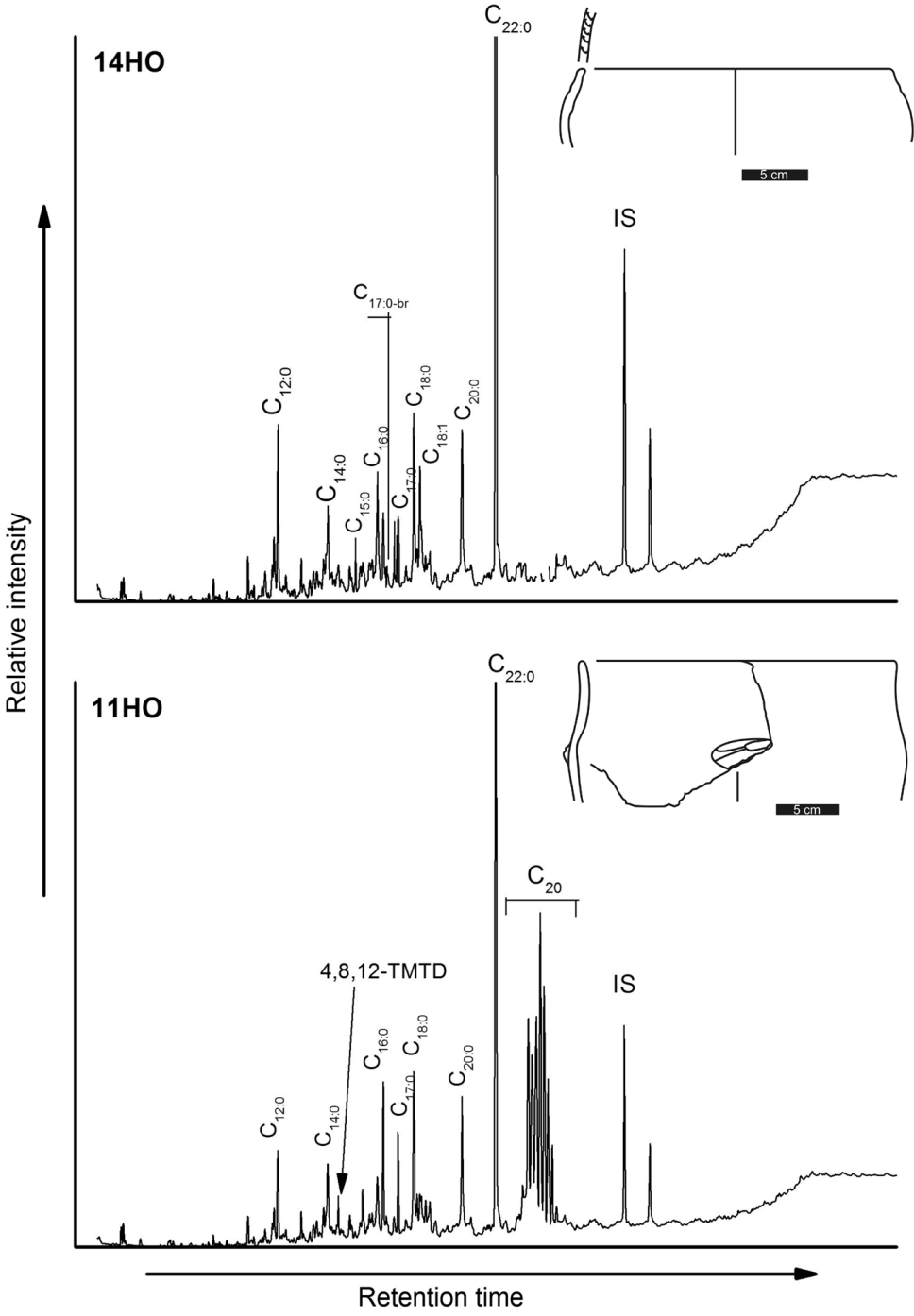

Fig. 6. The representative GC-MS total ion chromatograms of the fatty acids methylesters (FAMEs) with different $C_{16: 0}$ and $C_{18: 0}$ abundance extracted from the Hočevarica pottery samples $11 \mathrm{HO}$ and $14 \mathrm{HO}$.

$\mathrm{C}_{18: 1}$ were present in the lipid extracts of all samples (Tab. 1). The presence of odd number $\left(\mathrm{C}_{15: 0}\right.$ and $\mathrm{C}_{1700}$ ) and/or a low amount of branched chain of $\mathrm{C}_{17: 0}$ was determined in $50 \%$ of the pottery samples $(02 \mathrm{HO}, 05 \mathrm{HO}, 14 \mathrm{HO}, 20 \mathrm{HO}, 21 \mathrm{HO}, 22 \mathrm{HO}, 25 \mathrm{HO}$, $26 \mathrm{HO}, 27 \mathrm{HO}, 31 \mathrm{HO}, 33 \mathrm{HO}, 34 \mathrm{HO}, 36 \mathrm{HO})$. The presence of these acids together with two double bonds positional isomers of $\mathrm{C}_{18: 1}$ indicates ruminant animal fats that have been biosynthesised in the gut and rumen (Dudd et al. 1999; Regert 2011). The parallel biomarkers, i.e. triacylglycerols (TAGs) and their degradation products (diacylglicerols (DAGs) and monoacylglicerols (MAGs) were detected in 9 sherds $(02 \mathrm{HO}, 05 \mathrm{HO}, 14 \mathrm{HO}, 20 \mathrm{HO}, 21 \mathrm{HO}, 26 \mathrm{HO}, 27 \mathrm{HO}$, $34 \mathrm{HO}, 36 \mathrm{HO}$ ), confirming the presence of degraded animal fats (Tab. 2; Fig. 7). However, the TAG distribution could be identified in three sherds $(20 \mathrm{HO}$, $21 \mathrm{HO}$ and 26HO), while in the remaining samples only traces of TAGs were observed. The narrow distribution of TAGs in these three sherds, ranging from $\mathrm{C}_{42}$ to $\mathrm{C}_{52}$, indicates the presence of ruminant adipose or diary fats.

The presence of saturated and monosaturated fatty acids in a range from $\mathrm{C}_{20}$ to $\mathrm{C}_{24}$, together with a high proportion of $\mathrm{C}_{16: 0}$ and minor amounts of $\mathrm{C}_{12: 0}$ and $\mathrm{C}_{18: 0}$ acids are indicative of aquatic oils and thus provide evidence that freshwater foods were processed in these vessels (Hansel et al. 2004; Craig et al. 2011; 2013; Cramp et al. 2014). Such a lipid profile was observed in $35 \%$ of the samples $(04 \mathrm{HO}, 06$ $\mathrm{HO}, 09 \mathrm{HO}, 10 \mathrm{HO}, 11 \mathrm{HO}, 12 \mathrm{HO}, 13 \mathrm{HO}$, $17 \mathrm{HO}$ and 18HO). In addition, in these samples 4,8,12-trimethyltridecanoic acid (4,8,12-TMDT) at low concentrations was also identified. This component is a characteristic lipid biomarker of aquatic resources (Hansel et al. 2004) (Fig. 6).

Alongside the identification of animal or aquatic fats, a high percentage of samples $(81 \%)$ yielded the presence of beeswax lipids (Tab. 2). In five samples $(20 \mathrm{HO}, 21 \mathrm{HO}, 25 \mathrm{HO}, 26 \mathrm{HO}$, $36 \mathrm{HO}$ ) the lipid distribution indicate the high content of degraded beeswax lipids, while in other samples only traces of wax lipids are present. Beeswax lipids may indicate the addition of honey to other foodstuffs or the application of beeswax to pottery vessels to improve impermeability (Regert et al. 2001; Kimpe et al. 2002; Copley et al. 2005). Although in most of the samples only trace levels of this particular commodity were detected, its presence indicates that beeswax was utilised at Hočevarica in pottery vessels associated with cooking/processing foodstuffs or applied as a coating.

Long-chain ketones $\left(\mathrm{C}_{31}, \mathrm{C}_{33}\right.$ and $\left.\mathrm{C}_{35}\right)$ were observed in most samples with preserved lipids, except in 05HO. Long-chain ketones have been widely reported as components of the epicuticular waxes of higher plants (Walton 1990), but can be also formed from the condensation of fatty acids $\left(\mathrm{C}_{16: 0}\right.$ and $\left.\mathrm{C}_{18: 0}\right)$ during the heating of vessels to temperatures in excess of $400^{\circ} \mathrm{C}$ (Evershed et al. 1999). The presence of long-chain ketones together with thermally pro- 
Nives Ogrinc, Mihael Budja, Doris Potočnik, Andreja Žibrat Gašparič and Dimitrij Mlekuž

\begin{tabular}{|c|c|c|c|c|c|c|c|c|c|c|c|}
\hline $\begin{array}{l}\text { Lab. } \\
\text { sample } \\
\text { no. }\end{array}$ & ID. No. & Context & ${ }^{14 C}$ Lab. no. & $\begin{array}{l}\text { 14C conv. } \\
\text { age } \mathrm{BP}\end{array}$ & $\begin{array}{l}\text { Fabric } \\
\text { group }\end{array}$ & Desciption & $\begin{array}{c}\text { TLE } \\
\left(\mu \mathrm{g} \mathrm{g}^{-1}\right)\end{array}$ & $\begin{array}{l}\delta^{13 C} \\
\text { bulk } \\
\text { (\%o) }\end{array}$ & $\begin{array}{l}\delta^{15 \mathrm{~N}} \\
\text { bulk } \\
(\% \circ)\end{array}$ & $\begin{array}{c}\delta^{13} C_{16: 0} \\
(\% \circ)\end{array}$ & $\begin{array}{c}\delta^{13} \mathrm{C}_{18: 0} \\
(\% \circ)\end{array}$ \\
\hline $\mathrm{O} 1 \mathrm{HO}$ & 126 & phase 1 & Beta-391176 & $4860 \pm 30$ & calcite & vessel wall & 36.5 & -26.8 & 7.2 & -29.0 & -29.1 \\
\hline $\mathrm{O} 2 \mathrm{HO}$ & 165 & phase 1 & Beta-391177 & $4780 \pm 30$ & calcite & vessel wall & 25.3 & -29.1 & 4.9 & -28.0 & -29.2 \\
\hline $\mathrm{O} 3 \mathrm{HO}$ & 073 & phase 1 & & & calcite & vessel wall & 48.3 & -27.0 & 7.5 & $\mathrm{n} / \mathrm{d}$ & $n / d$ \\
\hline $\mathrm{O} 4 \mathrm{HO}$ & 075 & phase 1 & & & calcite & vessel rim with wall & 32.9 & -27.7 & 6.6 & -31.0 & -25.7 \\
\hline $05 \mathrm{HO}$ & 08० & phase 1 & & & calcite & dish & 39.0 & -27.3 & 5.5 & -27.8 & -27.4 \\
\hline ०6 HO & 135 & phase 1 & & & calcite & vessel wall & 96.5 & -27.9 & 7.4 & -31.1 & -27.3 \\
\hline$\overline{\mathrm{O}} \mathrm{7 \textrm {HO }}$ & 138 & phase 1 & & & calcite & vessel wall & 42.7 & -32.0 & -0.1 & -34.3 & -29.0 \\
\hline$\overline{\mathrm{O} 8 \mathrm{HO}}$ & 174 & phase 1 & & & calcite & vessel rim with wall & 40.8 & -27.4 & 0.4 & -29.8 & -28.2 \\
\hline$\overline{\mathrm{Og} \mathrm{HO}}$ & 087 & phase 1 & & & calcite & vessel rim with wall & 13.1 & -31.5 & 1.8 & -30.7 & -27.1 \\
\hline$\overline{\mathrm{OOHO}}$ & 076 & phase 1 & & & calcite & vessel rim with wall & 10.9 & -27.8 & 4.7 & -32.2 & -28.5 \\
\hline $11 \mathrm{HO}$ & PNoo81 & phase 1 & & & calcite & pot & 71.3 & -29.1 & 3.5 & -29.8 & -27.7 \\
\hline $12 \mathrm{HO}$ & 068 & phase $1 / 2$ & & & calcite & vessel rim with wall & 78.6 & -26.5 & 6.9 & -30.7 & -28.5 \\
\hline $13 \mathrm{HO}$ & 067 & phase $1 / 2$ & & & calcite & vessel wall & 37.8 & -27.0 & 3.7 & -32.4 & -27.6 \\
\hline $14 \mathrm{HO}$ & PNo135 & phase $1 / 2$ & & & calcite & pot & 51.5 & -27.5 & 1.8 & -25.5 & -27.9 \\
\hline $16 \mathrm{HO}$ & 049 & phase $1 / 2$ & & & calcite & vessel wall & 108 & -27.3 & 1.5 & -36.0 & -29.9 \\
\hline${ }_{17} \mathrm{HO}$ & 082 & phase 2 & & & calcite & vessel base with wall & 27.8 & -26.6 & 4.3 & -31.5 & -28.8 \\
\hline$\overline{18 \mathrm{HO}}$ & 088 & phase 2 & Beta-391181 & $4910 \pm 30$ & calcite & vessel wall & 5.9 & -28.4 & 4.9 & $n / d$ & $n / d$ \\
\hline$\overline{19 \mathrm{HO}}$ & 029 & phase 2 & & & calcite & vessel wall & 3.1 & -27.8 & 4.4 & $n / d$ & $n / d$ \\
\hline $2 \mathrm{OHO}$ & 032 & phase 2 & & & quartz & pot? & 211 & -30.7 & 4.8 & -27.3 & -33.9 \\
\hline $21 \mathrm{HO}$ & PNoO49 & phase 2 & & & quartz & dish & 63.3 & -30.5 & 4.8 & -26.7 & -28.5 \\
\hline $22 \mathrm{HO}$ & 035 & phase 2 & Beta-391182 & $4770 \pm 30$ & calcite & vessel wall & 29.2 & -27.3 & 6.3 & -29.8 & -29.1 \\
\hline $23 \mathrm{HO}$ & 020 & phase 2 & & & calcite & vessel wall & 23.6 & -27.0 & 5.8 & -30.6 & -26.8 \\
\hline $24 \mathrm{HO}$ & 017 & phase 2 & & & quartz & vessel rim with wall & 2.1 & -27.6 & 5.5 & $\mathrm{n} / \mathrm{d}$ & $\mathrm{n} / \mathrm{d}$ \\
\hline $25 \mathrm{HO}$ & 169 & phase 2 & & & quartz & vessel wall & 73.9 & -27.2 & 5.1 & -26.5 & -28.4 \\
\hline $26 \mathrm{HO}$ & 025 & phase 2 & & & quartz & dish & $53 \cdot 3$ & -27.3 & 5.2 & -28.4 & -29.2 \\
\hline $27 \mathrm{HO}$ & 019 & phase 2 & & & calcite & vessel wall & 15.9 & -27.2 & 4.4 & -30.3 & -31.4 \\
\hline $28 \mathrm{HO}$ & 120 & phase 1 & & & calcite & vessel wall & 1.6 & -28.2 & 4.6 & $\mathrm{n} / \mathrm{d}$ & $n / d$ \\
\hline $29 \mathrm{HO}$ & 121 & phase 1 & & & calcite & vessel wall & 6.0 & -29.3 & 5.6 & $n / d$ & $n / d$ \\
\hline $30 \mathrm{HO}$ & 089 & phase 1 & & & calcite & bowl & 4.7 & -26.5 & 6.7 & $\mathrm{n} / \mathrm{d}$ & $n / d$ \\
\hline $31 \mathrm{HO}$ & 085 & phase 1 & & & calcite & pot & 26.4 & -28.8 & 4.6 & -28.6 & -28.2 \\
\hline $32 \mathrm{HO}$ & 078 & phase 1 & & & calcite & vessel wall & 18.3 & -29.1 & 6.1 & $n / d$ & $n / d$ \\
\hline $33 \mathrm{HO}$ & 061 & planum $4 / 4$ & & & calcite & dish & 12.4 & -27.4 & 4.6 & -28.1 & -29.5 \\
\hline $34 \mathrm{HO}$ & 008 & $\mathrm{SU} 4 / 7$ & & & quartz & vessel wall & 7.0 & -28.9 & 3.3 & -26.3 & -27.2 \\
\hline $35 \mathrm{HO}$ & 003 & SU $1 / 2$ & & & calcite & vessel wall & 6.9 & -33.1 & 1.0 & $n / d$ & $n / d$ \\
\hline $36 \mathrm{HO}$ & $\mathrm{PNo138}$ & E cross-section & & & calcite & bowl? & 6.2 & -28.1 & 2.4 & -28.2 & -29.1 \\
\hline
\end{tabular}

Tab. 2. A summary of the organic residues detected in pottery samples from Hočevarica, Ljubljansko barje region. Key: MAG - moniacylglycerols; DAG - diacylglycerols; TAG - triacylglycerols; $A$ - n-alkanes; $\mathrm{OH}$ - n-alcohols; K - ketones; WE - wax esters; (tr) - trace; n/d - not detected. 


\section{$\Delta^{13} \mathrm{C} \quad \mathrm{C}_{16: 0} / \mathrm{C}_{18: 0}$ Fatty Acids (FA)}

(\%)

Other lipids

$0.0 \quad 1.48 \quad C_{12: 0}, C_{14: 0}, C_{16: 0}, C_{17: 1}, C_{18: 1}, C_{18: 0}, C_{20: 0}, C_{22: 0}$

\begin{tabular}{|c|c|c|}
\hline-1.2 & 1.45 & $\begin{array}{l}C_{12: 0}, C_{14: 0}, C_{15: 0}, C_{16: 0}, C_{17: 0-b r}, C_{17: 0}, C_{18: 1,}, C_{18: 0}, C_{20: 0}, \\
C_{22: 0}\end{array}$ \\
\hline$n / d$ & $\mathrm{n} / \mathrm{d}$ & $n / d$ \\
\hline 5.3 & 1.50 & $\begin{array}{l}C_{12: 0}, C_{14: 0}, T M D T, C_{16: 0}, C_{17: 1}, C_{17: 0}, C_{18: 1}, C_{18: 0}, C_{20: 0}, \\
C_{22: 0}\end{array}$ \\
\hline
\end{tabular}

3.8

$5 \cdot 3$

1.6

3.6

3.6

$3.7 \quad 1.97$

$2.1 \quad 0.94$

$2.2 \quad 1.15$

4.8

$-2.4 \quad 0.74$

$\mathrm{C}_{22: 0}$
$6.1 \quad 2.22 \quad C_{12: 0}, C_{14: 0}, T M D T, C_{15: 0}, C_{16: 0}, C_{17: 1}, C_{18: 1}, C_{18: 0}, C_{20: 0}$,

$\begin{array}{lll}6.1 & 22 & C_{22: 0} \\ & & \end{array}$

$2.7 \quad 1.35 \quad C_{12: 0}, C_{14: 0}, T M D T, C_{15: 0}, C_{15: 1,}, C_{16: 0}, C_{16: 1}, C_{17: 1}, C_{18: 1}$,

$\begin{array}{lll}n / d & n / d & n / d \\ n / d & n / d & n / d\end{array}$

$-6.6$

1.19

$C_{12: 0}, C_{14: 0}, C_{15: 0}, C_{16: 0}, C_{16: 1}, C_{17: 0-b r}, C_{17: 0}, C_{18: 1}, C_{18: 0}$ $C_{21: 0}, C_{20: 0}, C_{22: 0}, C_{24: 0}$

$C_{\text {6:0, }}, C_{16: 1,}, C_{17: 0-b r}, C_{17: 0,}, C_{18: 1}, C_{18: 0}$,

\begin{tabular}{lll}
-1.8 & 1.26 & $\begin{array}{l}\mathrm{C}_{12: 0}, \mathrm{C}_{14: 0}, \mathrm{C}_{15: 0}, \mathrm{C}_{16: 0}, \mathrm{C}_{17: 0}, \mathrm{C}_{18: 1}, \mathrm{C}_{18: 0}, \mathrm{C}_{20: 0}, \mathrm{C}_{22: 0}, \\
\mathrm{C}_{24: 0}\end{array}$ \\
\hline 0.7 & 1.22 & $\mathrm{C}_{12: 0}, \mathrm{C}_{14: 1}, \mathrm{C}_{15: 0}, \mathrm{C}_{16: 0}, \mathrm{C}_{17: 1,1}, \mathrm{C}_{17: 0,}, \mathrm{C}_{18: 1,}, \mathrm{C}_{18: 0}, \mathrm{C}_{20: 0}, \mathrm{C}_{22: 0}$ \\
\hline 3.8 & 2.02 & $\mathrm{C}_{12: 0}, \mathrm{C}_{14: 0}, \mathrm{C}_{16: 0}, \mathrm{C}_{18: 1,}, \mathrm{C}_{18: 0}, \mathrm{C}_{20: 0}, \mathrm{C}_{22: 0}$ \\
$\mathrm{n} / \mathrm{d}$ & $\mathrm{n} / \mathrm{d}$ & $\mathrm{n} / \mathrm{d}$
\end{tabular}

$\begin{array}{lll}\mathrm{n} / \mathrm{d} & \mathrm{n} / \mathrm{d} & \mathrm{n} / \mathrm{d} \\ -1.9 & 1.93 & \mathrm{C}_{12: 0}, \mathrm{C}_{14: 0}, \mathrm{C}_{15: 0}, \mathrm{C}_{16: 0}, \mathrm{C}_{17: 0}, \mathrm{C}_{18: 1}, \mathrm{C}_{18: 0}, \mathrm{C}_{20: 0}, \mathrm{C}_{22: 0}\end{array}$

$\begin{array}{lll}-1.9 & 1.93 & C_{12: 0}, \\ & C_{24: 0}\end{array}$

$-0.8 \quad 2.28$

$\begin{array}{lll}-1.1 & 0.85 & \begin{array}{l}\mathrm{C}_{12: 0}, \mathrm{C}_{14: 0}, \mathrm{C}_{15: 0}, \mathrm{C}_{15: 1,1}, \mathrm{C}_{16: 0}, \mathrm{C}_{17: 0-\mathrm{br}}, \mathrm{C}_{17: 0,0}, \mathrm{C}_{18: 1,}, \mathrm{C}_{18: 0}, \\ \mathrm{C}_{20: 0}, \mathrm{C}_{22: 0}\end{array} \\ \mathrm{n} / \mathrm{d} & \mathrm{n} / \mathrm{d} & \mathrm{n} / \mathrm{d} \\ \mathrm{n} / \mathrm{d} & \mathrm{n} / \mathrm{d} & \mathrm{n} / \mathrm{d} \\ \mathrm{n} / \mathrm{d} & \mathrm{n} / \mathrm{d} & \mathrm{n} / \mathrm{d}\end{array}$

$\mathrm{C}_{12: 0,}$

$\begin{array}{llll}n / d & n / d & n / d & n / d \\ n / d & n / d & n / d & \\ 0.4 & 1.11 & C_{12: 0,}, C_{14: 0}, C_{15: 0}, C_{15: 11}, C_{16: 0}, C_{17: 0}, C_{17: 1}, C_{18: 1}, C_{18: 0}, & \end{array}$

\begin{tabular}{|c|c|c|}
\hline & & $C_{2} \quad C_{2}$ \\
\hline$n / d$ & $\mathrm{n} / \mathrm{d}$ & $n / d$ \\
\hline-1.4 & 1.67 & $C_{12: 0}, C_{14: 0}, C_{16: 0}, C_{17: 0-b r}, C_{17: 0,}, C_{18: 1}, C_{18: 0}, C_{20: 0}, C_{22: 0}$ \\
\hline-1.0 & 0.24 & $C_{12: 0}, C_{14: 0}, C_{15: 0}, C_{15: 11}, C_{16: 0}, C_{16: 1}, C_{17: 0-b r}, C_{17: 0}, C_{18: 1,}$ \\
\hline
\end{tabular}

$\begin{array}{lll}n / d & n / d & n / d \\ -0.9 & 0.81 & C_{12: 0}, C_{14: 0}, C_{15: 0}, C_{16: 0}, C_{17: 0}, C_{18: 1}, C_{18: 0}, C_{20: 0}, C_{22: 0}\end{array}$

$\begin{array}{lll}\text { K, WE } & \text { mixture ruminant, plant } & \text { Not published } \\ \begin{array}{l}\text { K, WE, DAG (tr), } \\ \text { TAG }(\mathrm{tr})\end{array} & \text { ruminant } & \text { Not published } \\ \mathrm{K} & \mathrm{n} / \mathrm{d} & \text { Not published } \\ \mathrm{K} & \text { freshwater } & \text { Not published }\end{array}$

WE, DAG, TAG mixture ruminant,
non-ruminant

K, WE(tr) freshwater Not published

$\mathrm{K}, \mathrm{WE}(\mathrm{tr}) \quad$ non-ruminant $\quad$ Not published

$\mathrm{K}, \mathrm{WE}(\mathrm{tr}) \quad$ non-ruminant $\quad$ Not published

$\mathrm{K}, \mathrm{WE}(\mathrm{tr}) \quad$ freshwater $\quad$ Not published

$\mathrm{K}, \mathrm{WE}(\mathrm{tr}) \quad$ freshwater $\quad$ Not published

$\mathrm{K}, \mathrm{WE}(\mathrm{tr})$

$\mathrm{K}, \mathrm{WE}(\mathrm{tr})$

$\mathrm{K}, \mathrm{WE}(\mathrm{tr})$

K, WE, TAG(tr) ruminant

K, WE(tr) freshwater Not published

K, WE(tr) freshwater

$n / d \quad n / d$

$n / d \quad n / d$

$A, O H, K, W E, \quad$ mixture ruminant dairy

MAG, DAG, TAG fats and degraded

beeswax

$\mathrm{A}, \mathrm{OH}, \mathrm{K}, \mathrm{WE}, \quad$ mixture ruminant fats

DAG, TAG and degraded beeswax

$\mathrm{K}$ mixture ruminant, plant

$\mathrm{K}$

$\mathrm{n} / \mathrm{d}$

\section{A, OH, K, WE}

and degraded beeswax

$\mathrm{A}, \mathrm{OH}, \mathrm{K}, \mathrm{WE}, \quad$ mixture ruminant fats

MAG, DAG, TAG and degraded beeswax

$\mathrm{K}, \mathrm{DAG}(\mathrm{tr})$,

TAG (tr) ruminant

$\mathrm{n} / \mathrm{d} \quad \mathrm{n} / \mathrm{d}$

$n / d \quad n / d$

$n / d \quad n / d$

n/d

K, WE(tr)

mixture ruminant, plant Velušček 2004.PI. 4.1.3:3

\begin{tabular}{lll}
$\mathrm{n} / \mathrm{d}$ & $\mathrm{n} / \mathrm{d}$ & Not published \\
\hline $\mathrm{K}$ & ruminant & Velušček 2004.PI. 4.1.7:1 \\
$\mathrm{K}, \mathrm{TAG}, \mathrm{WE}(\mathrm{tr})$ & ruminant & Not published \\
$\mathrm{n} / \mathrm{d}$ & $\mathrm{n} / \mathrm{d}$ & Not published \\
$\mathrm{A}, \mathrm{OH}, \mathrm{K}, \mathrm{WE}$, & $\begin{array}{l}\text { mixture ruminant fats } \\
\text { DAG }(\mathrm{tr}), \mathrm{TAG}(\mathrm{tr})\end{array}$ & $\begin{array}{l}\text { and degraded beeswax } \\
\text { Veluščk 2004.PI. 4.1.7:3 }\end{array}$ \\
\hline
\end{tabular}

K, TAG, WE(tr) ruminant

$\begin{array}{lll}\mathrm{n} / \mathrm{d} & \mathrm{n} / \mathrm{d} & \text { Not published } \\ \mathrm{K} & \text { ruminant } & \text { Velušček 2004.Pl. 4.1.7:1 } \\ \mathrm{K}, \mathrm{TAG}, \mathrm{WE}(\mathrm{tr}) & \text { ruminant } & \text { Not published } \\ \mathrm{n} / \mathrm{d} & \mathrm{n} / \mathrm{d} & \text { Not published } \\ \mathrm{A}, \mathrm{OH}, \mathrm{K}, \mathrm{WE}, & \text { mixture ruminant fats } & \text { Velušček 2004.Pl. 4.1.7:3 } \\ \mathrm{DAG}(\mathrm{tr}), \mathrm{TAG}(\mathrm{tr}) & \text { and degraded beeswax } & \\ & & \end{array}$

Velušček 2004.PI. 4.1.8:1

Not published

Not published

Not published

Not published

Velušček 2004.PI. 4.1.10:2

Not published

Not published

Not published

Not published 
duced $\omega$-(o-alkylphenyl)alkanoic acids implies that their formation is mainly related to heating to high temperatures.

\section{Stable carbon isotope composition of fatty acids}

Further information regarding the source of the organic residues was obtained by measuring the stable carbon isotope ratio of saturated fatty acids $\mathrm{C}_{16: 0}$ and $\mathrm{C}_{18: 0}$ preserved in sufficient quantities in the pottery samples. The results were compared with modern reference animal data obtained from the literature presented in Figure 8 (Evershed et al. 2002; Copley et al. 2005; Craig et al. 2007; 2012).

Twelve samples $(04 \mathrm{HO}, 06 \mathrm{HO}, 07 \mathrm{HO}, 08 \mathrm{HO}, 09 \mathrm{HO}$, $10 \mathrm{HO}, 11 \mathrm{HO}, 12 \mathrm{HO}, 13 \mathrm{HO}, 16 \mathrm{HO}, 17 \mathrm{HO}$ and $23 \mathrm{HO})$ yielded $\delta^{13} \mathrm{C}$ values closer to those of lipid extracts from modern pottery vessels used to prepare freshwater and non-ruminant animals (Copley et al. 2005) (Fig. 8). Although nine of them $(04 \mathrm{HO}, 06 \mathrm{HO}, 09 \mathrm{HO}$, $10 \mathrm{HO}, 11 \mathrm{HO}, 12 \mathrm{HO}, 13 \mathrm{HO}, 16 \mathrm{HO}, 17 \mathrm{HO}$ ) have aquatic biomarkers present, their use cannot be resolved more specifically. Non-ruminant, terrestrial animal contribution/origin could not be excluded, since the animal bone assemblage contains a high percentage of boar/pig (>30\%) (Toškan, Dirjec 2004).

$35 \%$ of samples $(02 \mathrm{HO}, 14 \mathrm{HO}, 21 \mathrm{HO}, 25 \mathrm{HO}, 26 \mathrm{HO}$, $27 \mathrm{HO}, 33 \mathrm{HO}, 34 \mathrm{HO}, 36 \mathrm{HO}$ ) plot in the range for ruminant adipose fats (Fig. 8). The $\mathrm{C}_{16: 0} / \mathrm{C}_{18: 0}$ ratios of fatty acids for these samples range between 0.74 and 2.28 values (Tab. 2) typical of ruminant adipose fat (Copley et al. 2005). The distribution of the data (Fig. 8) and $\delta^{15 \mathrm{~N}}$ values of samples (average value $4.4 \pm 1.2 \%$ ) suggested that the population at Hočevarica used diverse domesticated (goat, cattle) or wild (deer) animal products in their diet. The sample $20 \mathrm{HO}$ plots in the region typical of ruminant dairy fats. The processing of dairy products in this pottery vessel is further supported by the distribution of lipids (Fig. 7).

A further $15 \%$ of the samples (01HO, 05HO, 22HO, 31HO) fall close to the limit value between non-ruminant and ruminant fat $\left(\Delta^{13} \mathrm{C}=\delta 13 \mathrm{C}_{18: 0}-\right.$ $\delta^{13} \mathrm{C}_{16: 0}=0 \%$ ). However, not all samples could be assigned to meat mixtures exclusively. In vegetable oils, for example, the $\mathrm{C}_{18: 1}$ fatty acid is enriched in ${ }^{13} \mathrm{C}$ compared to $\mathrm{C}_{18: 0}$ (Spangenberg, Ogrinc 2001). A ${ }^{13} \mathrm{C}$ enrichment of $\mathrm{C}_{18: 1}$ (up to $2.3 \%$ ) compared to $\mathrm{C}_{18: 0}$ acid was also observed in three pottery vessels $(01 \mathrm{HO}, 22 \mathrm{HO}$ and $31 \mathrm{HO})$ suggesting an admixture of plant-animal fats.

\section{Conclusions}

The results of stable isotope data and the more specific product identification based on available lipids indicate varied vessel use: pots were used to cook both aquatic and terrestrial products.

The ruminant animal fats of either domestic (cattle, goat) or wild (deer) origin were the most frequently processed products preserved in the Hočevarica pottery samples (Tab. 2; 02HO, 05 HO, 14HO, 21HO, $22 \mathrm{HO}, 25 \mathrm{HO}, 26 \mathrm{HO}, 27 \mathrm{HO}, 31 \mathrm{HO}, 33 \mathrm{HO}, 34 \mathrm{HO}, 36-$ HO). These samples come from all the analysed settlement phases at Hočevarica and display a variety of different types and technologies (both the calcite/ limestone group and the quartz group). This confirms that ruminant animal fat was processed in a variety of vessels, such as pots $(14 \mathrm{HO}, 31 \mathrm{HO})$, dishes $(21 \mathrm{HO}, 26 \mathrm{HO}, 33 \mathrm{HO})$ and bowls $(05 \mathrm{HO}, 36 \mathrm{HO})$ (Fig. 4).

The processing of non-ruminant animal fats was detected in only three samples from Hočevarica that come from both main settlement phases, all made from the most common technological group with added calcite/limestone inclusions (Tab. 2; 07HO, 08$\mathrm{HO}, 23 \mathrm{HO}$ ).

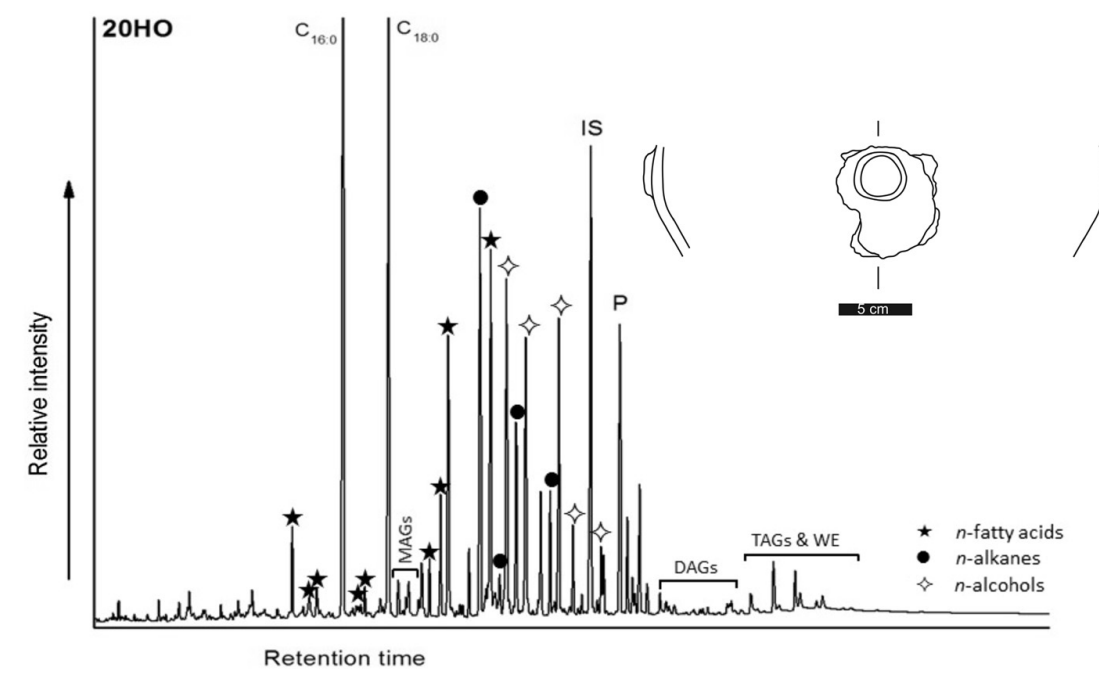

Fig. 7. Partial high-temperature gas chromatogram showing total lipid extracts from pottery sample $20 \mathrm{HO}$ from Hočevarica that is characteristic of a mixture of ruminant dairy fat and degraded beeswax. 

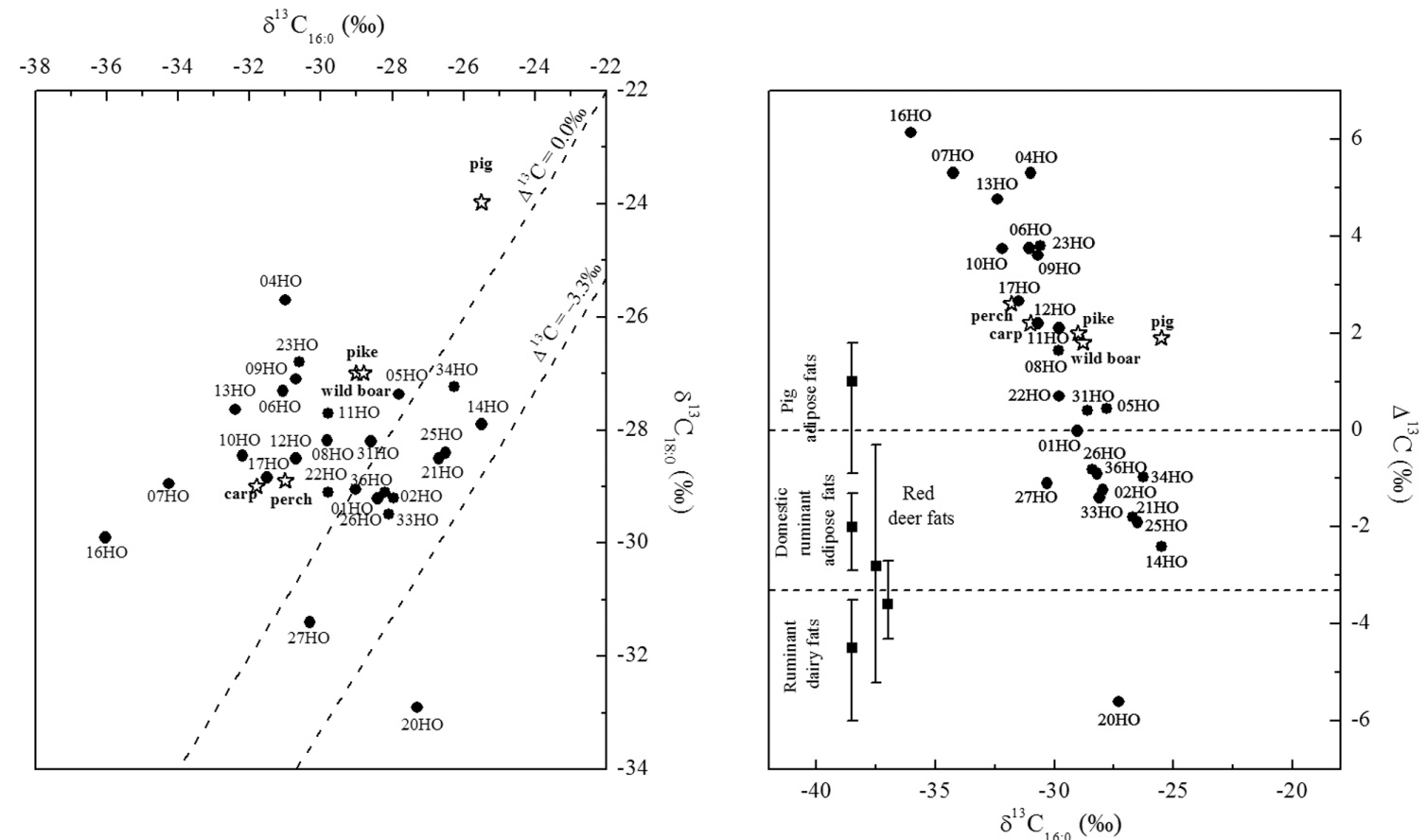

Fig. 8. Plot showing: $A)$ the $\delta^{13} C_{18: 0}$ versus $\delta^{13} C_{16: 0}$ values of some modern reference animal fats and archaeological samples; $B$ ) the difference in the $\delta^{13} C$ values of $C_{18: 0}$ and $C_{16: 0}$ fatty acids $\left({ }^{13} C\right)$ versus ${ }^{13} \mathrm{C}_{16: 0}$ recovered from pottery extracts from Hočevarica. Also shown are the data from modern reference fat: is data from Craig et al. (2007) and the median and ranges of $\delta^{13} \mathrm{C}$ from animals fed exclusively on $C_{3}$ diets. The pig adipose fats and ruminant adipose and dairy fats are from Copley et al. (2005), while the wild ruminants are from the UK (Evershed et al. 2002) and red deer from Poland (Craig et al. 2012). All isotope data have been adjusted for the effects of post-industrial carbon (Friedl et al. 1986) in order to compare them with archaeological data.

Only one decorated pot with an appliqué (20HO) indicates the processing of dairy fat. This pot dates to the $2^{\text {nd }}$ settlement phase at Hočevarica and was made with the less common fine-grained fabric with quartz inclusions (Fig. 4; Tab. 2).

The appearance of aquatic biomarkers is associated with nine samples $(04 \mathrm{HO}, 06 \mathrm{HO}, 09 \mathrm{HO}, 10 \mathrm{HO}, 11$ $\mathrm{HO}, 12 \mathrm{HO}, 13 \mathrm{HO}, 16 \mathrm{HO}$ and $17 \mathrm{HO}$ ), indicating that these vessels were used in the preparation of aquatic resources such as fish and molluscs (Tab. 1). One of the samples with aquatic biomarkers is a pot with an appliqué (11HO; Fig. 4). Most of the samples come from the oldest settlement phase at Hočevarica and have similar technological characteristics in terms of their inclusions (calcite/limestone group), surface and firing treatment. This group of vessels also includes the only samples with a grey-black slip on the surface (10HO).

Moreover, we found that three of the pottery samples $(01 \mathrm{HO}, 22 \mathrm{HO}$ and $31 \mathrm{HO})$ were used to process both plant and animal fats. These samples also come from all the settlement phases and are made with calcite/limestone inclusions. Sample $31 \mathrm{HO}$ is also a pot with an appliqué and comes from the same con- text as pot $11 \mathrm{HO}$, which showed the presence of aquatic biomarkers (Fig. 4; Tab.2).

The presence of beeswax in the vessels suggests either the storage of honey or the use of beeswax as a waterproofing agent. Beeswax was detected in five samples (Tab. 2; 20HO, 21HO, 25HO, 26HO, 36HO), of which four come from the $2^{\text {nd }}$ settlement occupation phase and fall into the group with quartz inclusions. As to their morphology, the samples with preserved beeswax include two dishes $(21 \mathrm{HO}, 26-$ $\mathrm{HO}$ ), one pot that was also used to process dairy fat (20HO), and one bowl (36HO) (Fig. 4). These results suggest that the use of beeswax as a waterproofing agent or the use of honey in the preparation of food was more common in the younger settlement phase at Hočevarica and/or connected to special types of vessels made with a different ceramic fabric.

\section{ACKNOWLEDGEMENTS}

The research was undertaken as part of research projects J6-4085 funded by the Slovenian Research Agency. We thank the Ljubljana City Museum and our colleague Irena Šinkovec for providing access to the Hočevarica pottery and fish bone assemblages. 


\section{References}

Bregant T. 1974a. Kolišče ob Maharskem prekopu pri Igu - raziskovanja leta 1970. Poročilo o raziskovanju neolita in eneolita Slovenije 3: 7-34.

1974b. Kolišče ob Maharskem prekopu pri Igu - raziskovanja leta 1972. Poročilo o raziskovanju neolita in eneolita Slovenije 3: 39-66.

1975. Kolišče ob Maharskem prekopu pri Igu - raziskovanja 1973. in 1974. leta. Poročilo o raziskovanju neolita in eneolita Slovenije 4: 7-106.

Budja M., Ogrinc N., Žibrat Gašparič A., Potočnik D., Žigon D. and Mlekuž D. 2013. Transition to farming - transition to milk culture: a case study from Mala Triglavca, Slovenia. Documenta Praehistorica 40: 97-117.

Copley M. S., Berstan R., Dudd S. N., Straker V., Payne S. and Evershed R. P. 2005. Dairy in antiquity, I: evidence from absorbed lipid residues dating to British Iron Age. Journal of Archaeological Science 32: 485-503.

Craig O. E., Forster M., Andersen S. H., Koch E., Crombé P., Milner N. J., Stern B., Bailey G. N. and Heron C. P. 2007. Molecular and isotopic demonstration of the processing of aquatic products in Northern European prehistoric pottery. Archaeometry 49: 135-152.

Craig 0. E., Allen R. B., Thompson A., Stevens R. E., Steele V. J. and Heron C. 2012. Distinguishing wild ruminant lipids by gas chromatography/combustion/isotope ratio mass spectrometry. Rapid Communication in Mass Spectrometry 26: 2359-2364.

Craig 0. E. and 13 authors 2013. Earliest evidence for the use of pottery. Nature 496: 351-354.

Cramp L. J., Jones J., Sherdin A., Smyth J., Whelton H., Mulville J., Sharples N. and Evershed R. P. 2014. Immediate replacement of fishing with dairying by the earliest farmers of the northeast Atlantic archipelagos. Philosophical Transactions of the Royal Society B, 281: 20132372.

Čufar K., Kromer B., Korenčič T. and Velušček A. 2010. Dating of $4^{\text {th }}$ millennium BC piledwellings on Ljubljansko barje, Slovenia. Journal of Archaeological Science 37(8): 2031-2039.

Čufar K., Kromer B. 2004. Radiocarbon dating of tree-ring chronologies from Hočevarica. In A. Velušček (ed.), Hočevarica. An Eneolithic pile dwelling in the Ljubljansko barje. Opera Instituti Archaeologici Sloveniae 8. ZRC SAZU Publishing. Ljubljana: 281-285.

Dudd S. N., Evershed R. P. and Gibson A. M. 1999. Evidence for varying patterns of exploitation of animal pro- ducts in different prehistoric pottery traditions based on lipids preserved in surface and absorbed residues. Journal of Archaeological Science 26: 1473-1482.

Evershed R. P., Heron C. and Goad L. J. 1990. Analysis of Organic Residues of Archaeological Origin by High-Temperature Gas Chromatography/Mass Spectrometry. Analyst 115: 1339-1342.

Evershed R. P., Arnot K. I., Eglinton G. and Charters S. 1994. Application of isotope ratio monitoring gas chromatography-mass spectrometry to the analysis of organic residues of archaeological origin. Analyst 119: 909-914.

Evershed R. P., Dudd S. N., Charters S., Mottram H., Stott A. W., Raven A., van Bergen P. F. and Bland H. A. 1999. Lipids as a carriers of anthropogenic signals from prehistory. Philosophical Transactions of the Royal Society B, 354: 19-31.

Evershed R. P., Dudd S. N., Copley M. S. and Mukherjee A. 2002. Identification of animal fats via compound specific ${ }^{13} \mathrm{C}$ values of individual fatty acids: Assessment of results for reference fats and lipid extracts of archaeological pottery vessels. Documenta Praehistorica 21: 73-96.

Friedl H., Lotscher H., Oescher H., Siegenthaler U. and Stauffer B. 1986. Ice core record of the ${ }^{13} \mathrm{C} /{ }^{12} \mathrm{C}$ ratio of atmospheric $\mathrm{CO}_{2}$ in the past two centuries. Nature 324: 237-238.

Govedič M. 2004. Fishes from the archaeological site at Hočevarica. In A. Velušček (ed.), Hočevarica. An Eneolithic pile dwelling in the Ljubljansko barje. Opera Instituti Archaeologici Sloveniae 8. ZRC SAZU Publishing. Ljubljana: 133-151.

Gregg M. W., Slater G. F. 2010. A new method for extraction, isolation and transesterification of free fatty acids from archaeological pottery. Archaeometry 52: 833-854.

Hansel F. A., Copley M. S., Madureira L. A. and Evershed R. P. 2004. Thermally produced $\omega$-(o-alkylphenyl) alcanoic acids provide evidence for the processing of marine products in archaeological pottery vessels. Tetrahedron Letters 45: 2999-3002.

Horvat M. 1999. Keramika: tehnologija keramike, tipologija lončenine, keramični arhiv. Znanstveni inštitut Filozofske fakultete. Ljubljana.

Jeraj M. 2004. Palaeobotanical analyses of the Hočevarica pile dwelling. In A. Velušček (ed.), Hočevarica. An Eneolithic pile dwelling in the Ljubljansko barje. Opera Instituti Archaeologici Sloveniae 8. ZRC SAZU Publishing. Ljubljana: 56-64. 
2009. The diet of Eneolithic (Copper Age, Fourth millennium cal B.C.) pile dwellers and the early formation of the cultural landscape south of the Alps: a case study from Slovenia. Vegetation History and Archaeobotany 18: $75-89$

Katzenberg A. M., Weber A., 1999. Stable isotope ecology and paleodiet in the Lake Baikal region of Siberia. Journal of Archaeological Science 26: 651-659.

Kimpe K., Jacobs P. A. and Waelkens M. 2002. Mass spectrometric methods prove the use of beeswax and ruminant fats in late Roman cooking pots. Journal of Chromatography A 968: 151-160.

Miller J. M., Capriles J. M. and Hastorf A. 2010. The fish of Lake Titicaca: implications for archaeology and changing ecology through stable isotope analysis. Journal of Archaeological Science 37: 317-327.

Mottram H. R., Dudd S. N., Lawrence G. J., Stott A. W. and Evershed R. P. 1999. New chromatographic, mass spectrometric and stable isotope approaches to the classification of degraded animal fats preserved in archaeological pottery. Journal of Chromatography A 833: 209-21.

Mukherjee A. J., Berstan R., Copley M. S., Gibson A. M. and Evershed R. P. 2007. Compound-specific stable carbon isotopic detection of pig product processing in British late Neolithic pottery. Antiquity 81(313): 743-54.

Ogrinc N., Budja M. 2005. Paleodietary reconstruction of a Neolithic population in Slovenia: A stable isotope approach. Chemical Geology 218: 103-116.

Ogrinc N., Gams Petrišič M., Žigon D., Žibrat Gašparič A. and Budja M. 2012. Pots and lipids: molecular and isotope evidence of food processing at Maharski prekop. Documenta Praehistorica 39: 339-347.

Polet C., Katzenberg M. A. 2003. Reconstruction of the diet in the mediaeval monastic community from the coast of Belgium. Journal of Archaeological Science 30: 525533.

Privat K. L., O'Connell T. and Richards M. P. 2002. Stable isotope analysis of human and faunal remains from the Anglo-Saxon cemetery at Berinsfield, Oxfordshire: Dietary and social implication. Journal of Archaeological Science 29: 779-790.

Regert M., Colinart S., Degrand L. and Decavallas 0. 2001. Chemical alteration and use of beeswax through time: accelerated ageing test and analysis of archaeological samples from various environmental contexts. Archaeometry 43(4): 549-569.
Regert M. 2011. Analytical strategies for discriminating archeological fatty substances from animal origin. Mass Spectrometry Reviews 30: 177-220.

Rice P. M. 1987. Pottery Analysis. A Sourcebook. The University of Chicago Press. Chicago and London.

Richards M. P., Pearson J. A., Molleson T. I., Russell N. and Martin L. 2003. Stable isotope evidence of diet at Neolithic Çatalhöyük, Turkey. Journal of Archaeological Science 30: 67-76.

Spangenberg J. E., Ogrinc N. 2001. Authentication of vegetable oils by bulk and molecular carbon isotope analyses - with emphasis on olive oil and pumpkin seed oil. Journal of Agricultural and Food Chemistry 49: 15341540.

Spangenberg J. E., Jacomet S. and Schibler J. 2006. Chemical analyses of organic residues in archaeological pottery from Arbon Bleiche 3, Switzerland - evidence for dairying in the late Neolithic. Journal of Archaeological Science 33: 1-13.

Tolar T., Jacomet S., Velušček A. and Čufar K. 2011.Plant economy at a late Neolithic lake dwelling site in Slovenia at the time of the Alpine Iceman. Vegetation History and Archaeobotany 20: 207-222.

Toškan B., Dirjec J. 2004. Hočevarica - an analysis of macrofauna remains. In Velušček A. (ed.), Hočevarica. An Eneolithic pile dwelling in the Ljubljansko barje. Opera Instituti Archaeologici Sloveniae 8. ZRC SAZU Publishing. Ljubljana: 76-132.

Velušček A. (ed.) 2004a. Hočevarica. An Eneolithic pile dwelling in the Ljubljansko barje. Opera Instituti Archaeologici Sloveniae 8. ZRC SAZU Publishing. Ljubljana.

2004b. Field research, stratigraphy and the material finds. In A. Velušček (ed.), Hočevarica. An Eneolithic pile dwelling in the Ljubljansko barje. Opera Instituti Archaeologici Sloveniae 8. ZRC SAZU Publishing. Ljubljana: 33-40.

2004c. Analysis of the stratigraphic distribution of finds. In A. Velušček (ed.), Hočevarica. An Eneolithic pile dwelling in the Ljubljansko barje. Opera Instituti Archaeologici Sloveniae 8. ZRC SAZU Publishing. Ljubljana: 213-217.

2004d. Hočevarica: pottery. In A. Velušček (ed.), Hočevarica. An Eneolithic pile dwelling in the Ljubljansko barje. Opera Instituti Archaeologici Sloveniae 8. ZRC SAZU Publishing. Ljubljana: 169-212. 
Walton T. J. 1990 Waxes, cutin and suberin. In J. L. Harwood, J. R. Bowyer (eds.), Methods in plant biochemistry. Vol. 4. Academic Press, London: 105-158.

Žibrat Gašparič A. 2013. A new look at old material: ceramic petrography and Neo/Eneolithic pottery traditions in the eastern Ljubljansko barje, Slovenia. Documenta Praehistorica 40: 147-164.

Žibrat Gašparič A., Horvat M. and Mirtič B. 2014. Ceramic petrography, mineralogy and typology of Eneolithic pottery from Krašnja, Slovenia. Documenta Praehistorica 41: 225-236. 